\title{
Human capital, innovation capability and economic growth in Portugal, 1960-2001*
}

\author{
Aurora A.C. Teixeira and Natércia Fortuna \\ CEMPRE, Faculdade de Economia da Universidade do Porto, 4200-464 Porto, Portugal \\ (e-mail: ateixeira@fep.up.pt; nfortuna@fep.up.pt)
}

Received: November 2003 / Accepted: November 2004

\begin{abstract}
In maintaining that the main flaw in empirical studies on economic growth derives from the fact that they employ Solow-style neoclassical growth models, rather than testing actual endogenous growth theory, we examine the human capital-innovation-growth nexus, thus testing new growth theory more directly. We test its insights against the economic evolution of an individual country, Portugal, using time series data from 1960 to 2001. Estimates based on vector autoregressive and cointegration analysis seem to confirm that human capital and indigenous innovation efforts were enormously important to the economic growth process in Portugal during the period of study. In particular, the indirect effect of human capital through innovation, emerges here as being critical, showing that a reasonably high stock of human capital is necessary to enable a country to reap the benefits of its indigenous innovation efforts.
\end{abstract}

Keywords: Human capital - Innovation - Economic growth - Cointegration

JEL Classification: C22, J24, O30, O40

\footnotetext{
* The authors are grateful to two anonymous referees, Paulo Brito and the participants of the 2003 Portuguese Society for Economics Research (SPiE) in Lisbon, Portugal for helpful comments and suggestions. CEMPRE - Centro de Estudos Macroeconómicos e Previsão - is supported by the Fundação para a Ciência e a Tecnologia, Portugal, through the Programa Operacional Ciência, Tecnologia e Inovação (POCTI) of the Quadro Comunitário de Apoio III, which is financed by FEDER and Portuguese funds. 


\section{Introduction}

The role of human capital as one of the sources of growth has been given little attention by authors writing about economic growth in both the classical and neoclassical tradition. In the 1980s, the seminal works of Romer (1986) and Lucas (1988) revolutionized the neoclassical theory of economic growth by introducing endogenous growth models. These new neoclassical theories put emphasis not on direct sources of economic growth, but on the mechanisms and incentives linked to the actual dynamics of growth. One of the most distinctive features of the 'new' theories of growth has been the increasing importance attributed to human capital and productive knowledge and to the interaction between these two factors (Lucas, 1988; Romer, 1989; Azariadis and Drazen, 1990; Mankiw et al., 1992).

In policy terms, human capital and knowledge accumulation have been given high priority. In fact, the strategy outlined at the 2002 Lisbon Summit, aimed at making the European Union the most competitive and dynamic knowledge based economy in the world, put investment in human capital at the forefront of those policies aimed at promoting economic growth and social cohesion (de la Fuente, 2003b; de la Fuente and Ciccone, 2002).

Even though many economists and policy-makers consider human capital to be an important production factor, complemented by technological capital, and studies that focused on cross-country growth performance over long periods have generally yielded positive results (e.g., Barro, 1991; Barro and Lee, 1994; Mankiw et al., 1992), there is evidence in the literature of uncertainty concerning the impact on aggregate growth of investment in education. Some of the best-known studies (Benhabib and Spiegel, 1994; Caselli et al., 1996; Prichett, 1995) have produced rather disappointing results in this regard.

Recent works (Sianesi and van Reenen, 2003; de la Fuente and Doménech, 2002; Cohen and Soto, 2001; Wossmann, 2003) suggest that the negative results are largely due to the poor quality of data on education, which has produced high measurement errors and hidden the connection between human capital and productivity.

While acknowledging that the quality of data is important, in this paper we argue that the main problem is that empirical studies on economic growth, rather than testing growth endogenous theory itself, use Solow-style neoclassical growth models. Pack (1994) in commenting on the paucity of systematic tests of endogenous growth theory, stressed that using cross-country regressions to explain growth rates produces irregular orders of magnitude and indications of where to search for explanations of growth, without articulating the connection between factor accumulation and economic growth. In this sense, "[t]he challenge for empirical work is to test the implications of the new theory more directly. In practice, this means testing its insights against the economic evolution of individual countries using time series data" (Pack, 1994, p. 70).

A better understanding of the real sources of economic growth at individual country level is required, therefore, to investigate the human capital-innovationgrowth nexus. A few empirical works have employed a comparable line of research using time series data (e.g., Teixeira, 1996; Chuang, 2000; Pina and St. Aubyn, 2002). 
The purpose of this paper is to analyze the soundness of human capital-based endogenous growth theory employing appropriate estimation techniques to calculate the long-run relationship between human capital, innovation capability and productivity for Portugal during the period 1960-2001. As we will demonstrate, the variables in our model exhibit strong time trends, that is, unit roots are present in the data. In this case, the use of conventional estimation techniques (based on classical hypotheses about the properties of the perturbation term) would result in inaccurate statistical inferences (Rao, 1994) potentially leading to nonsensical (or spurious) results (Granger and Newbold, 1974; Harris, 1995). Developments in time series analysis (Engle and Granger, 1987; Johansen, 1988) advocate cointegration techniques as being the most adequate method for estimating models containing non-stationary variables.

The paper is structured as follows. In Section 2, we briefly portray, on the basis of the existing literature, the relationship between human capital, technological progress and economic growth. In Section 3, we describe the data set that we use and in Section 4 we describe the empirical study of a long-run stable relationship between productivity, human capital and innovation capability. Finally, Section 5 concludes with a summary of estimation results for the Portuguese economy during the period 1960-2001.

\section{Human capital, innovation and economic growth: a review}

In spite of the contributions of various authors, both preceding and contemporary with Solow, it was this author who first conducted a systematic and quantified analysis of the questions related to economic growth, clearly distinguishing between economic growth from economic development (Solow, 1956).

The basic neoclassical model of economic growth, associated with the pioneering work of Solow (1956) assumes, however, that disembodied technological progress (as well as population growth and workforce) is exogenous to the model. ${ }^{1}$ New theories of economic growth (Romer, 1986; Lucas, 1988) went beyond the limits of exogenous technological innovation underlying the work of Solow, and considered the accumulation of human capital as a determinant of economic growth.

Human capital is necessary for the production of goods, services and knowledge. Its importance has increased as production processes become more knowledge intensive (de la Fuente, 2003a, 2004). Several authors have found that investment in human capital contributes significantly to productivity (Sianesi and van Reenen, 2003; de la Fuente and Ciccone, 2002) in pointing out that human capital plays a key role in fostering technological change and diffusion.

New technology and skilled labor are complementary (Doms et al., 1997; Autor et al., 1998; Berman et al., 1998) - the more access that people have to knowledge, the greater will be its likely economic benefits. In particular, the spread of knowledge

\footnotetext{
1 The term "disembodied" means that the pace of investment does not influence the rate at which technology improves. It is as “... all technical progress were something like time-and-motion study, a way of improving the organization and operation of inputs without reference to the nature of the inputs themselves." (Solow, 1956, pp. 90-91).
} 
depends on learning potentials linked to human capital stock. A large stock of human capital in a country facilitates that country's absorption of new products and new ideas and discoveries (Nelson and Phelps, 1966; Barro and Lee, 2000). This highlights the importance of a nation's 'social capability' (Abramovitz, 1986) and 'absorptive capacity' (Cohen and Levinthal, 1990).

Although the idea of inseparability between technology, innovation and human capital had already been expressed in the economics literature of the 1960s and 1970s (Cipolla, 1965; Nelson and Phelps, 1966; Mansfield, 1975; Rosenberg, 1976), it was only in the mid-1980s that the issue was taken up seriously by economists. This culminated, in the second half of the 1980s, in the so-called 'new growth theories' (Romer, 1986; Lucas, 1988), which can be seen as the formalization of rather 'old' ideas.

Theoretical models of human capital and economic growth are built around the hypotheses that knowledge and skills embodied in human capital directly raise productivity (Becker, 1962; Schultz, 1961) and increase an economy's ability to develop and to adopt new technologies (Nelson and Phelps, 1966).

For most new growth models, a determinant of economic growth is endogenous innovation. Presently, it is common to suppose that new technologies are the driving force of long-run productivity growth (Coe et al., 1995; Griliches, 1995; Caballero and Jaffe, 1993; and Coe and Helpman, 1995). However, this innovative action is itself influenced by the endowment of human capital in the economy. ${ }^{2}$ Using crosscountry data, Benhabib and Spiegel (1994) modeled technological progress as a function of education level and, as in Romer (1990a), considered the hypothesis that human capital affects growth not only directly (influencing the technological innovation rate of a country), but also indirectly (influencing the pace of absorption of technological-related knowledge). ${ }^{3}$ The results obtained by these authors suggest that the role of human capital, as a necessary condition for absorption and creation of technology adapted to internal needs, is more important than its role in production.

In order to explore its implications and open the way for its empirical testing, this basic hypothesis is formalized in two not mutually exclusive ways. First, the stock of human capital can be introduced as an additional input in an otherwise standard production function linking aggregate output to the stocks of productive inputs (employment and physical capital) and to an index of total factor productivity. Then, the stock of human capital can be included as a determinant of the rate of technological progress, through its interaction with the stock of technological knowledge. This involves specifying a total factor productivity function, which includes both variables related to human capital and R\&D stock and an interaction term for these two variables. ${ }^{4}$

2 These models of endogenous growth share Arrow's (1962) idea of the existence of important externalities inherent to the accumulation process of technological knowledge.

3 This idea is not novel. Nelson and Phelps (1966) have already suggested that technical progress (or the residual of Solow) depends on the gap between the knowledge level of a country and the level of "theoretical knowledge". For these authors, the rate at which this gap reduces depends on the level of human capital.

4 We have disregarded physical capital accumulation here. This does not mean that we want to convey the view that physical capital is unrelated to human capital and unimportant for a country's total factor productivity, but rather that our focus here is on the human capital-innovation-growth nexus. A similar 
The approach adopted in our paper constitutes novelty in the sense that these two strands are often analyzed as two distinct groups of theoretical views about the relationship between human capital and economic development (cf. Aghion and Howitt, 1998): the 'neoclassical' view (the accumulation of human capital as a factor of production driving economic growth) and the 'technical-progress' view (a greater human capital stock affects economic growth mainly by facilitating innovation and adoption of new knowledge and technologies).

\section{The proxies for relevant variables}

\subsection{Total factor productivity}

In the theoretical literature on economic growth, technological progress is viewed in three ways: as a free good (Solow, 1956), as a byproduct (externality) of other economic activities (Arrow, 1962; Romer, 1986) and as the result of R\&D activities undertaken by private firms (Romer, 1990a; Grossman and Helpman, 1991; Aghion and Howitt, 1992; Segerstrom, 1991; Caballero and Jaffe, 1993). The first two forms of technological progress share certain merits. On the one hand, basic research conducted at universities and other public R\&D institutions supplies substantial inputs for technological progress. On the other hand, learning-by-doing, practice and interaction are important factors in technological progress. The third form of technological progress, innovation as a result of activities undertaken by private firms, is, however, increasingly seen as being the most relevant source of technological progress in capitalist economies.

The most commonly used measures of economic growth are output per worker (or hours per worker) and total factor productivity (TFP) or "residual of Solow". The output per worker measures productivity growth as the difference between the growth rate in the output index based on gross domestic product (GDP) at constant prices and an employed population index or the number of hours per worker. The second measure, TFP, subtracts from the first measure an estimate of the contribution of physical capital to productivity growth, based on the growth of the capital/labor ratio, weighted by the capital factor share on total returns relative to all the factors. ${ }^{5}$

In this study, TFP is used as a proxy for technological progress, although we are aware of its limitations. As Abramovitz (1993) puts it “. . . TFP (total factor productivity) ... is properly interpreted as reflecting the influence of all the unmeasured sources of growth ... it includes, besides technological advance, also changes in labour quality due to education or otherwise, gains from the better allocation of resources and those from the economies of scale - unless these are somehow measured."

line was adopted by Coe and Helpman (1995), who conclude that the possibility of physical capital accumulation does not affect the result that differences in cumulative R\&D and, in our case also human capital stock, could explain differences in total factor productivity.

5 Both measures are associated with the problems of determining an adequate price index as a GDP deflator, and of measuring the quantity and quality of labor factor; the second measure has the additional problem of the quantification of capital and its rate of use (Griliches, 1988). 


\subsection{Human capital stock}

Many lines of economic research depend on having an accurate measure of individual human capital, which, in turn, requires investment in education and other inputs to human capital to be measured. Measurement problems are particularly acute in the case of human capital (Hanushek, 1996). A review of the measures of the stock of human capital used in empirical growth research reveals that human capital is generally poorly proxied (Wossmann, 2003). Notwithstanding this, there has been considerable work expended to improve international measures of human capital (Barro and Lee, 2000). De la Fuente and Doménech (2002) show that improvement in data quality leads to larger and more precise estimates of schooling coefficients in growth regressions.

Alternative proxies for human capital encompass school enrolment ratios, adult literacy rates, levels of education attainment and average years of schooling, monetary value of human capital stock and international test scores of students.

The first two proxies were extensively used in growth regressions (Mankiw et al., 1992; Levine and Renelt, 1992; Barro, 1991; Azariadis and Drazen, 1990; Romer, 1990b) on the ground of their easy availability and broad coverage. However, adult literacy rates ignore most of the investments made in human capital as they do not include qualifications obtained above the basic levels of education. In relation to school enrolment ratios, they constitute a poor measure of the stock of human capital available for current production. Enrolment ratios are flow variables, and the children currently enrolled in schools are by definition not yet part of the labor force. Therefore, enrolment ratios may not even accurately represent changes in human capital stock, especially during periods of rapid educational and demographic transition.

Given the shortcomings of existing human capital proxies, levels of education and average years of schooling (cross-country data: Barro and Lee, 1993, 1996, 2002; Kyriacou, 1991; Psacharopoulos and Arriagada; 1986; and time series data: Teixeira, 1996, 1998; Pereira, 2004) have become the most popular and commonly used measures. Educational attainment is clearly a stock variable, and it takes into account the total amount of formal education received by the labor force. Nevertheless, specifying human capital by average years of schooling implicitly gives the same weight to any year of schooling acquired by a person and ignores the fact that one-year of schooling does not raise the human capital stock by an equal amount regardless of the quality of the education system that provided it.

Alternative proxies, such as money value of human capital stock (Laroche and Mérette, 2000; Pereira, 2004) do not assume that the productivity differential among workers is proportional to the differential in educational attainment. This proxy tries to capture differences in the quality of education as well as the market relevance of different types of education and of working experience. However, there are potential problems with the available estimates of return to education because of biases arising from unmeasured characteristics such as ability, and because of their the disregard of social benefits (Barro and Lee, 2000), and, in the case that wages change substantially, this measure tends to fluctuate unnecessarily (Mulligan and Sala-i-Martin, 1995). 
International test scores for students provide useful information on the quality of education and the international adult literacy survey (OECD and Human Resources Development Canada, 1998) represents a major attempt to measure directly the skills of the labor force for international comparison. Nevertheless, these measures are at present restricted by the limited size of the sample. Therefore, data on educational attainment still provide the best available information about the amount of human capital stock of a country.

This study uses average years of schooling of the working age population as a proxy for human capital stock following the methodology of Teixeira $(1996,1998)$ to extend the series of human capital till 2001 (Teixeira, 2004a). ${ }^{6}$

\subsection{Internal stock of knowledge or innovation capability}

Knowledge stock has been approximated by various proxies: number of scientists and engineers (Jones, 1995; Kortum, 1994), patented inventions (Fagerberg, 1987; Kortum, 1994), strength of R\&D - R\&D/GDP ratio (Griliches, 1988), total expenditure on R\&D (Coe and Helpman, 1995; Coe et al., 1995) and others.

Quantifying the contribution of R\&D to economic growth has proved to be particularly complicated, firstly, because of the impossibility of measuring productivity precisely, especially in sectors intensive in $R \& D$ and services (that have increased in respect to the rest of economy), and secondly because of the impossibility of correctly estimating the dimension of $R \& D$ spillovers between firms, industries and countries.

Fagerberg (1987) divides measures of technological level and technological activities into two types: technological input measures (expenditures on education, expenditures on $\mathrm{R} \& \mathrm{D}$, employment of scientists and engineers) and technological output measures (patents). Measures of the first type are directly related to the innovation capability of a country and also to its own imitation capability, in the way that a certain level of the science base is necessary for the imitation process to be successful. Technological output measures are only related to innovation activity - the innovation of methods of production and products.

In this study, we favor technological input measures (more precisely, accumulated expenditures on R\&D) because economic growth in Portugal has been characterized more by the absorption and diffusion of knowledge, than by its creation (Verspagen, 1993). In line with the empirical work of Coe and Helpman (I 995), we use accumulated expenditures on $\mathrm{R} \& \mathrm{D}$ as a proxy for knowledge stock (innovation capability). Thus, we constructed a proxy of internal knowledge stock for Portugal, based on the internal expenditures on research and development of firms. ${ }^{7}$

6 Pina and St. Aubyn (2002) also estimate a time series for human capital using the methodology described in Teixeira (1996). They, however, introduce some methodological changes and consider a more comprehensive concept of human capital, which, besides schooling, includes professional training. These authors have also recognized that this use of a more comprehensive concept does not significantly change the results obtained.

7 For more details on the methodology used and estimation results, see Teixeira (2004b). 


\section{Specification and estimation of the econometric model}

\subsection{Specification of the econometric model}

The purpose of this section is to estimate the long-run structural relations between total factor productivity, human capital and innovation capability (knowledge stock) for the Portuguese economy in the period 1960-2001.

These structural relations are based on a log-linear specification of the joint evolution of total factor productivity (proxy for technological progress), internal stock of knowledge (total accumulated expenditure on R\&D) and human capital stock (average number of years of schooling):

$$
f_{t}=\beta_{1,0}+\beta_{1,1} h_{t}+\beta_{1,2} i s k_{t}+u_{1 t},
$$

where $f_{t}$ is the (natural) logarithm of the total factor productivity level, for the year $t$; $h_{t}$ is the logarithm of the average number of years of schooling (proxy for human capital), for the year $t ; i s k_{t}$ is the logarithm of the total accumulated expenditures on $R \& D$ (proxy of internal stock of knowledge or internal innovation capability), for the year $t ; \beta_{1,1}$ and $\beta_{1,2}$ are the TFP elasticities with respect to human capital stock and internal stock of knowledge, respectively; and, finally, $u_{1 t}$ is a random perturbation term.

The theory suggests that productivity tends to increase when human capital stock $h$ grows, ceteris paribus. It also suggests that a larger innovation capability, reflected by a larger internal stock of knowledge $i s k$, is associated with greater productivity. Therefore, productivity will be positively related to human capital stock and innovation capability, that is, $\beta_{1,1}>0$ and $\beta_{1,2}>0$.

In the case that the theory is valid, we expect that any departure in productivity, concerning long-run equilibrium (expressed by the equation above), will necessarily be of a temporary nature. Therefore, an additional basic assumption of the theory is that the sequence $u_{1 t}$ is stationary.

In order to analyze potential interactions between human capital and innovation capability (internal stock of knowledge), we estimate in addition the following relations

$$
\begin{aligned}
& f_{t}=\beta_{2,0}+\beta_{2,1} h_{t}+\beta_{2,2} h_{i s k_{t}+u_{2 t}} \\
& f_{t}=\beta_{3,0}+\beta_{3,1} h_{t}+\beta_{3,2} i s k_{t}+\beta_{3,3} h i s k_{t}+u_{3 t},
\end{aligned}
$$

where $h i s k_{t}=H_{t} i s k_{t}$ with the index $H_{t}$ of the average number of years of schooling, for the year $t$.

If $\beta_{2,2}, \beta_{3,3}>0$, then the effect of the internal stock of knowledge on productivity tends to be greater when the population is more educated; or, in other words, the effect of human capital stock on productivity is directly related to the magnitude of the internal stock of knowledge.

Total factor productivity, human capital and internal stock of knowledge proxies exhibit strong trends, that is, they are non-stationary. In this case, the use of conventional estimation methods (based on the classical hypotheses on perturbation terms) in the models that include such variables, tend to lead to erroneous 
statistical inference (Rao, 1994). Statistical reliability of classical estimation methods is based on the hypothesis that variable means and variances are well-defined, time independent constants. However, when means and variances change with time (non-stationary variables), all statistics that use such means and variances will also be dependent on time and therefore do not converge to the true (population) values when sample size tends towards being infinite. Moreover, hypothesis tests, based on those statistics, will also be biased towards the rejection of the null hypothesis of absence of a relation between the dependent and independent variables. Thus, in the presence of non-stationary variables, the use of conventional estimation methods also brings the danger of obtaining "spurious regression" (Granger and Newbold, 1974), whose estimates are deprived of any economic meaning. Studies of time series analysis (Engle and Granger, 1987; Johansen, 1988), point to cointegration techniques as the most adequate estimation method when the variables of a model are non-stationary.

Given the characteristics of non-stationarity inherent in the series of our study, we judge that the use of classical estimation methods would be unsatisfactory and, guided by the latest econometric advances in time series analyses, we decided to opt for use of cointegration techniques.

\subsection{Estimation of the model}

Cointegration allows to estimate equilibrium, or long-run parameters, in a relationship that includes unit root (non-stationary) variables. In this study, the use of this econometric analysis is motivated, on the one hand, by an interest in estimating long-run relationships between total factor productivity, human capital and innovation capability of the Portuguese economy and, on the other hand, by the statistical properties of considered time series. The econometric software EViews 5.0 ${ }^{\mathbb{R}}$ was used in the estimation. The three considered time series exhibit strong trends, noticeable in Figure 1 (in Appendix B) and confirmed by the tests for non-stationarity (presented in Tables 4-6 in Appendix C).

The idea behind cointegration is that, in the long-run, if two or more series evolve together, then a linear combination of them might be stable around a fixed mean, despite their individual trends (which cause non-stationarity). Thus, when there is a long-run relationship between variables, the regression of all the variables (cointegrating regression) has stationary perturbation terms, even though no variable, individually considered, is stationary. ${ }^{8}$

The results of Augmented Dickey-Fuller (ADF) (Dickey and Fuller, 1979; 1981) and Phillips-Perron (PP) (Phillips and Perron, 1988) tests applied to the variables in this study, indicate that twice differenced series are stationary, that is, the variables will be integrated at, at most, second order, i.e. $I(2)$. Comparing the values of

\footnotetext{
8 In technical terms, the class of non-stationary series contains a special group composed of integrated known variables, having important statistical properties of significance at the level of economics relationships. A series $y_{t}$ is said to be integrated at order $d$, denoted by $I(d)$, if $\Delta^{d} y_{t}=(1-L)^{d} y_{t}$ is a stationary series (where $L$ is a backshift operator: $L y_{t}=y_{t-1}$ ). In other words, a series is integrated to the order $d$ if it becomes stationary when differenced $d$ times.
} 
the test statistics obtained with the corresponding critical values, we conclude that all variables differenced once are stationary (that is, they do not have unit roots). Thus, it is reasonable to suppose that all the series in the model are at most $I(1)$. Finally, we can conclude from Table 5 that the (level) variables of the model are non-stationary (the statistical evidence does not reject a non-stationarity hypothesis - the existence of a unit root).

From the above we can conclude that the series of the model are $I(1)$. Consequently, the series could perhaps be cointegrated (Dickey et al., 1991), that is, there could be one or more stationary linear combinations of the series, suggesting a stable long-run relationship between them.

Since the number of cointegration vectors is unknown, and since it is necessary to guarantee that all variables are potentially endogenous (and then to test for exogeneity), it seems wise to use the methodology developed by Johansen (Johansen, 1988; Johansen and Juselius, 1990).

Let $z_{t}$ be a vector of $n$ potentially endogenous variables. The vector autoregressive (VAR) representation of the data generation process of $z_{t}$, having $k$ lags, can be written as: ${ }^{9}$

$$
z_{t}=A_{1} z_{t-1}+\ldots+A_{k} z_{t-k}+u_{t}, \quad u_{t} \sim \operatorname{IN}(0, \Sigma) .
$$

Reformulated as a Vector Error-Correction Model (VECM), this becomes:

$$
\Delta z_{t}=\Gamma_{1} \Delta z_{t-1}+\ldots+\Gamma_{k-1} \Delta z_{t-k+1}+\Pi z_{t-k}+u_{t}
$$

where

$$
\begin{array}{ll}
\Gamma_{i}=-\left(I-A_{1}-\ldots-A_{i}\right), & i=1, \ldots, k-1 \\
\Pi=-\left(I-A_{1}-\ldots-A_{k}\right), & \Pi=\alpha \beta^{\prime}
\end{array}
$$

with the matrix $\beta$ of long-run parameters and the matrix $\alpha$ of the parameters of velocity adjustment. Thus, VECM contains information on adjustments of the variations of $z_{t}$ both in the short and long-run, via $\Gamma_{i}$ and $\Pi$, respectively. Assuming that $z_{t}$ is a vector of non-stationary series $I(1)$, the series $\Delta z_{t-k}$ are $I(0)$. For $u_{t}$ to be white noise, $\Pi z_{t-k}$ has also to be stationary (that is, $I(0)$ ). This happens when there are $r \leq(n-1)$ cointegrating vectors in $\beta$, that is, when $r$ columns of $\beta$ form $r$ linearly independent combinations between the variables included in $z_{t}$, each of these combinations being stationary. In Johansen's methodology, determining the number of vectors $r$ is equivalent to testing for the reduced rank of the matrix $\Pi$. Thus, the number of cointegrating vectors can be obtained by testing for significance of the eigenvalues of the matrix $\Pi$. These tests can be carried out through the following test statistics:

$$
\begin{aligned}
& \lambda_{\text {trace }}(r)=-T \sum_{i=r+1}^{n} \ln \left(1-\hat{\lambda}_{i}\right) \\
& \lambda_{\max }(r, r+1)=-T \ln \left(1-\hat{\lambda}_{r+1}\right)
\end{aligned}
$$

9 The VAR model is a way of estimating dynamic relationships between potentially endogenous variables, not imposing, a priori, strong restrictions on exogeneity of the variables and on their structural relationships. 
where $\hat{\lambda}_{i}$ are the eigenvalue estimates obtained from $\hat{\Pi}$ and $T$ is the number of observations. ${ }^{10}$

As mentioned above, the structural regression to be estimated involves a relationship between productivity, human capital stock and innovation capability (internal stock of knowledge) for the Portuguese economy in the period 1960-2001, expressed by (1)-(3).

In cointegration notation, using (3), the vectors of potentially endogenous variables $z_{t}$ and the normalized cointegrating vectors $\beta$ 's can be represented as

$$
z_{t}=\left(f_{t} h_{t} i s k_{t} h i s k_{t}\right), \quad \beta_{i}=\left(1-\beta_{1 i}-\beta_{2 i}-\beta_{3 i}\right) .
$$

Actually, we estimate two regressions, the basic one mentioned above, and an additional one, which includes a step-dummy for 1984. The justification for its inclusion derives from two interrelated facts.

One concerns the different path of evolution of returns to education in Portugal before and after the mid-1980s. Hartog et al. (2001) found that the returns to education were very stable during the first half of the 1980s, but increased substantially in the second half, more precisely with Portugal's accession to the European Union. In this period, Portugal experienced trade changes and modernization of the industrial structure, namely through the introduction of new production technologies. The liberalization of trade, with more developed countries producing capital goods, stimulated technology imports, which required labor endowed with high levels of human capital.

The second fact, which is technical, relates to results based on the Chow test, which indicated statistically significant changes in structure for the time series in analysis in that period, indicating the advisability of including a time dummy.

Before testing for cointegration, one should determine the number of lags for an unrestricted VAR model. For the econometric specification considered, we set the lag order to that suggested by the Akaike information criteria (AIC), which was 3 . In order to carry out the cointegration test, we also needed to make an assumption regarding the trend underlying our data. We allowed for a linear deterministic trend in the level data, but the cointegrating equations only have intercepts because we believe all trends are stochastic. In the period 1960-2001, the $\lambda_{\text {trace }}$ and $\lambda_{\max }$ tests do not reject the hypothesis that there is one cointegrating vector. Choosing $r=1$, we obtain the estimates of the cointegrating vectors presented in Table 2.

We also applied the Johansen procedure to test whether there is a cointegration relationship between the TFP, the human capital and the internal stock of knowledge (described in (1)). We found evidence against the hypothesis that these three variables are cointegrated. We also examined the case of the structural relationship (2) but the results obtained albeit with the right signs and statistical significance

10 The $\lambda_{\text {trace }}$ statistic tests the null hypothesis that the number of cointegrating vectors is less than or equal to $r$ against the alternative hypothesis that there are $n$ vectors. The $\lambda_{\max }$ statistic tests the null hypothesis that the number of cointegration vectors is $r$, against the alternative hypothesis that there are $r+1$ vectors. 
Table 1. Results of Johansen's cointegration test. Portugal, 1960-2001

\begin{tabular}{ccrcrr}
\hline$r$ & $\hat{\lambda}_{i}$ & $\lambda_{\text {trace }}$ & $p$-value & $\lambda_{\max }$ & $p$-value \\
\hline none & 0.5494 & 56.2699 & 0.0067 & 31.0882 & 0.0170 \\
at most 1 & 0.3078 & 25.1817 & 0.1550 & 14.3471 & 0.3372 \\
at most 2 & 0.2318 & 10.8347 & 0.2218 & 10.2841 & 0.1939 \\
at most 3 & 0.0140 & 0.5506 & 0.4581 & 0.5506 & 0.4581 \\
\hline
\end{tabular}

MacKinnon at al. (1999) $p$-values.

Table 2. Estimates of the long-run TFP elasticities. Portugal, 1960-2001

\begin{tabular}{ccc}
\hline Variables & No time dummy & Step-dummy for 1984 \\
\hline Human capital (direct effect) & 0.4186 & 0.4205 \\
& $(0.2255)$ & $(0.2131)$ \\
Internal stock of knowledge & 0.3040 & 0.2781 \\
(indigenous innovation capability) & $(0.1845)$ & $(0.1927)$ \\
Innovation absorption capability & 0.4021 & 0.3610 \\
(human capital indirect effect, through innovation) & $(0.1229)$ & $(0.1541)$ \\
\hline
\end{tabular}

Estimated standard error in parenthesis.

show a remarkably high estimate for human capital elasticity. This seems to indicate that this coefficient estimate includes the effect of the missing variable $i s k{ }^{11}$

According to the economic theory underlying the model, TFP is positively related to the human capital stock and innovation capability (internal stock of knowledge) of an economy. Moreover, the long-run parameter associated with the variable that takes into account interactions between human capital stock and innovation capability hisk is theoretically expected also to be positive, meaning that the elasticity of total factor productivity with respect to internal stock of knowledge $\beta_{3 i} H$ is larger for higher levels of schooling of the population. In other words, the influence of internal stock of knowledge on productivity is a positive function of the human capital stock of the economy.

Therefore, the estimated cointegration relationships are consistent with theoretical presumptions. The evidence shows that Portuguese productivity has benefited from human capital (education) more than from the investments in internal innovation capability. More precisely, focusing on the period 1960-2001, we estimate that a 1 percentage point increase in the average number of years of schooling for the Portuguese population (aged 25 years or older) leads, for a fixed level of knowledge, to an increase in the productivity of the economy of about 0.42 percentage points. The importance of indigenous innovation efforts, even if to a lesser extent than human capital, appears here as well highlighted. In fact, a 1 percentage point increase in the internal stock of knowledge tends, ceteris paribus, to increase productivity by 0.30 percentage points. In addition to the direct effect mentioned

\footnotetext{
${ }^{11}$ Normalized cointegrating coefficients (standard error in parenthesis)

\begin{tabular}{ccc}
\hline$f$ & $h$ & hisk \\
\hline 1.0000 & -0.9018 & -0.5516 \\
& $(0.1744)$ & $(0.1362)$
\end{tabular}
}


above, human capital also indirectly influences total factor productivity through innovation; specifically, the results obtained demonstrate that the elasticity of total factor productivity with respect to the internal stock of knowledge is larger for higher levels of schooling of the population (i.e., the long-run elasticity with respect to innovation absorption capability is 0.40 percentage points). The introduction of the step-dummy did not fundamentally change the results. Human capital continues to emerge as the essential variable. Note that, despite some methodological differences, the estimates obtained for human capital elasticities are similar to those in Pina and St. Aubyn (2002), who studied the long-run relationship between physical (public and private) capital, human capital and economic growth in Portugal during the period 1977-2001.

These results are also, to an extent, confirmed by other empirical studies. Estimates of the parameters seem to confirm that human capital and indigenous innovation efforts are enormously important to the process of economic growth in Portugal during the period of study. Notwithstanding, the relevance of human capital direct effect comes out greater than that involving the creation of an internal basis of R\&D (indigenous innovation efforts). Coe and Helpman (1995) and Verspagen (1993) have reported that the internal stock of knowledge is not the fundamental variable in the process of economic growth in small open economies such as Portugal. Although the relevance of the internal innovation efforts is seen, in our study, as being much more important than these authors suggest, the capability for absorption of innovation does seem to be more important than domestic innovation efforts per se.

In summary, using an approach, which articulates the connection between factor accumulation and economic growth and, thus, directly tests endogenous growth theory (cf. Pack, 1994), the case of Portugal supports human capital-based endogenous growth theory. That is, there is evidence of the existence of a stable long-run relationship between human capital, innovation capability and productivity for Portugal during the period 1960-2001. Moreover, the indirect effect of human capital, through innovation, emerges here as critical, denoting the importance of a reasonably high stock of human capital, which enables a country to reap the benefits of its indigenous innovation efforts.

\section{Conclusions}

The main goal of this work was to investigate the effects of human capital on economic growth, measured by the growth of total factor productivity, roughly considered as an approximation of technological progress. This goal was achieved by empirically testing the main hypotheses found in the literature within this area, namely that greater aggregated economic activity will be caused by a higher endowment in human capital and/or a greater innovation capability (these two factors being interrelated, as more human capital tends to stimulate the innovation capability of an economy). We estimated structural (long-run) relationship between total factor productivity (proxy of technological progress), human capital stock (average number of years of schooling), internal innovation capability (internal stock of knowledge - measured by the real total accumulated expenditure on firm R\&D), and 
absorption capability (composite variable involving human capital stock and the internal stock of knowledge). Due to inherent characteristics of variables (evidence of strong trends), this estimation was carried out using cointegration techniques, specifically the Johansen methodology.

The main estimation results emphasize that human capital stock and internal innovation capability (internal stock of knowledge) are important in explaining Portuguese productivity during the period of study, though the impact and significance of the former outweighs the latter. More precisely, the estimate of elasticity of total factor productivity with respect to human capital stock is 0.42 percentage points, against 0.30 percentage points for the analogous estimate of the internal stock of knowledge. Moreover, the elasticity of TFP with respect to innovation absorption capability is 0.40 percentage points. These values, in addition to confirming a stable long-run relationship between productivity, human capital and internal innovation capability, also indicate that human capital is extremely important for Portuguese economic growth, directly, through its impact on productivity and indirectly, by facilitating the absorption of new knowledge thereby enhancing the impact of new knowledge on productivity.

\section{A Time series used to compute relevant variables}

The time series used to compute the relevant variables are presented in Table 3.

Table 3. Time series used to compute relevant variables

\begin{tabular}{lcccccc}
\hline Year & GDP & Labour & $\begin{array}{c}\text { Physical } \\
\text { capital stock }\end{array}$ & TFP Index & $\begin{array}{c}\text { R\&D stock or } \\
\text { internal stock } \\
\text { of knowledge }\end{array}$ & $\begin{array}{c}\text { Human } \\
\text { capital stock }\end{array}$ \\
\hline 1960 & 2464368 & 3309 & 4919 & 0.468003 & 1966.0 & 1.36 \\
1961 & 2566396 & 3295 & 5047 & 0.482590 & 2007.8 & 1.45 \\
1962 & 2807537 & 3299 & 5137 & 0.523197 & 2078.2 & 1.56 \\
1963 & 2975382 & 3318 & 5287 & 0.545379 & 2154.3 & 1.68 \\
1964 & 3067390 & 3359 & 5350 & 0.555466 & 2315.4 & 1.84 \\
1965 & 3230505 & 3440 & 5286 & 0.580951 & 2423.6 & 2.01 \\
1966 & 3518268 & 3518 & 5576 & 0.609727 & 2549.1 & 2.13 \\
1967 & 3477995 & 3535 & 5591 & 0.600417 & 2613.4 & 2.25 \\
1968 & 3818754 & 3550 & 5837 & 0.644640 & 2799.8 & 2.33 \\
1969 & 3843836 & 3599 & 6051 & 0.633249 & 2973.2 & 2.53 \\
1970 & 4199176 & 3637 & 6338 & 0.673102 & 3197.4 & 2.74 \\
1971 & 4606770 & 3682 & 6795 & 0.709999 & 3477.3 & 2.88 \\
1972 & 4983097 & 3748 & 7310 & 0.735084 & 3840.3 & 2.98 \\
1973 & 4959212 & 3796 & 7562 & 0.715076 & 4171.9 & 3.12 \\
1974 & 5000901 & 3781 & 7891 & 0.708289 & 4463.5 & 3.23 \\
1975 & 4474037 & 3696 & 7369 & 0.662372 & 4686.0 & 3.34 \\
1976 & 4774313 & 3624 & 7145 & 0.724586 & 4770.6 & 3.38 \\
1977 & 4882417 & 3672 & 7171 & 0.734666 & 5021.2 & 3.47 \\
1978 & 5393675 & 3770 & 7392 & 0.788996 & 5054.2 & 3.55 \\
1979 & 5669101 & 3862 & 7837 & 0.796516 & 5394.9 & 3.72 \\
\hline & & & & & &
\end{tabular}


Table 3 (continued)

\begin{tabular}{lcccccc}
\hline Year & GDP & Labour & $\begin{array}{c}\text { Physical } \\
\text { capital stock }\end{array}$ & TFP Index & $\begin{array}{c}\text { R\&D stock or } \\
\text { internal stock } \\
\text { of knowledge }\end{array}$ & $\begin{array}{c}\text { Human } \\
\text { capital stock }\end{array}$ \\
\hline 1980 & 5683577 & 3944 & 7791 & 0.791993 & 5836.3 & 3.91 \\
1981 & 6126696 & 3939 & 8417 & 0.823638 & 6260.3 & 4.24 \\
1982 & 6218352 & 3965 & 8872 & 0.812669 & 6795.0 & 4.41 \\
1983 & 5873156 & 3879 & 8675 & 0.784835 & 7111.5 & 4.59 \\
1984 & 5926447 & 3937 & 8349 & 0.799996 & 7739.0 & 4.74 \\
1985 & 6188363 & 3932 & 8185 & 0.843802 & 8061.6 & 4.69 \\
1986 & 6529012 & 3900 & 8188 & 0.893951 & 8713.4 & 4.90 \\
1987 & 7593006 & 4007 & 9106 & 0.974828 & 9247.6 & 4.96 \\
1988 & 7727170 & 4096 & 9907 & 0.942369 & 9942.4 & 5.10 \\
1989 & 8429756 & 4236 & 10823 & 0.968716 & 10606.8 & 4.91 \\
1990 & 9047713 & 4279 & 11622 & 1.000000 & 11661.6 & 5.15 \\
1991 & 9385634 & 4335 & 12329 & 1.001975 & 12367.4 & 5.41 \\
1992 & 9849644 & 4360 & 13151 & 1.016960 & 13344.3 & 5.46 \\
1993 & 10126309 & 4295 & 13904 & 1.026491 & 14269.8 & 5.62 \\
1994 & 10130336 & 4293 & 14310 & 1.013318 & 15152.0 & 5.80 \\
1995 & 10480499 & 4315 & 14837 & 1.027795 & 15815.4 & 5.90 \\
1996 & 11724515 & 4251 & 15853 & 1.123343 & 17128.1 & 6.53 \\
1997 & 12263903 & 4332 & 17011 & 1.125343 & 18005.1 & 6.67 \\
1998 & 12823638 & 4739 & 18166 & 1.087946 & 19680.2 & 6.82 \\
1999 & 13305785 & 4825 & 19444 & 1.082854 & 21090.0 & 7.00 \\
2000 & 13793738 & 4909 & 20839 & 1.076714 & 22991.8 & 7.19 \\
2001 & 14058502 & 4989 & 21638 & 1.068853 & 25720.0 & 7.41 \\
\hline & & & & & \\
\hline
\end{tabular}

Notes: GDP at constant prices of 1990 in million contos (1000 PTE); labor - people employed (thousand); physical capital stock in thousand contos was estimated by permanent inventory method using Gross Capital Formation (GFCF) and a depreciation rate of 10\%; TFP index (1990 = 100) was computed using the formula $F=Y /\left(L^{\alpha} K^{1-\alpha}\right)$, where $\alpha$ is the average (19852001) labor share in total income (52.9\%); the accumulated R\&D expenditures (thousand contos) were computed by permanent inventory method using R\&D expenditures and a depreciation rate of 5\%; $\mathrm{H}$ - average schooling years of the Portuguese adult population (25 years old or more). Sources: GDP; GFCF; labor - "Séries Longas do banco de Portugal"; GDP deflator - Barreto, A. (Org.) (1999), A Situação Social em Portugal, 1960-1999; Physical capital stock in 1960 Neves (1994), The Portuguese Economy in Figures; R\&D expenditures - JNICT, Observatório para a Ciência e Tecnologia and Observatório para a Ciência e Ensino Superior.

\section{B Plots of the variables in levels}

Plots of the variables in levels are presented in Figure 1. 


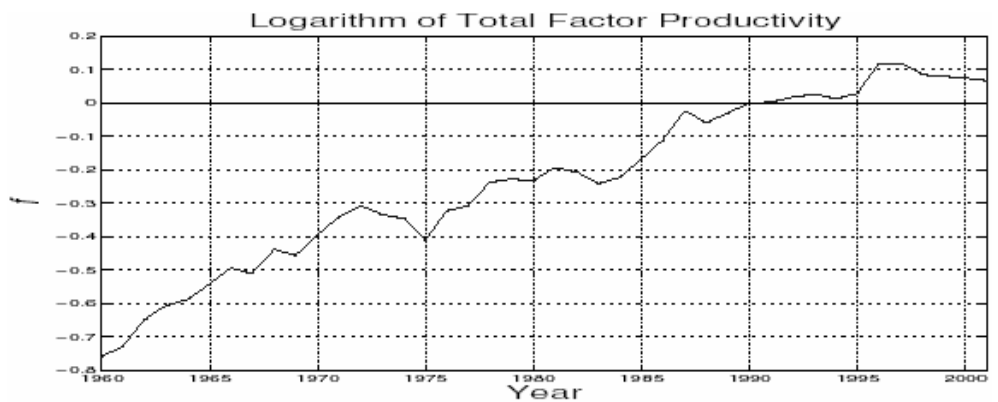

Logarithm of Human Capital Stock

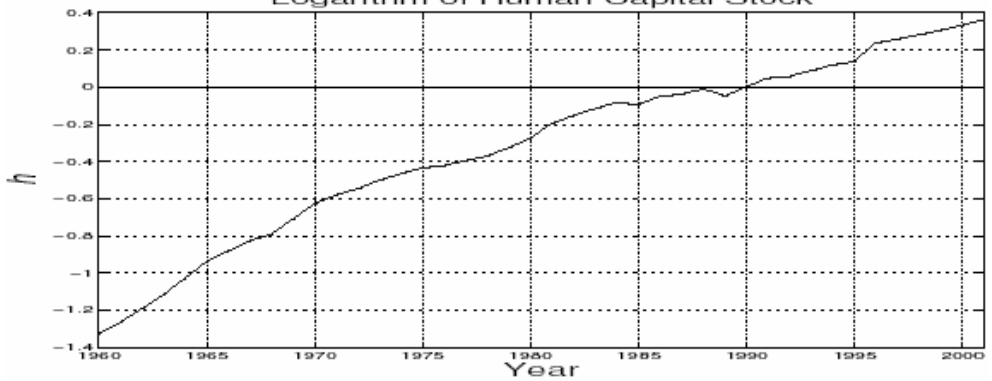

Logarithm of Internal Stock of Knowledge

ऊँ
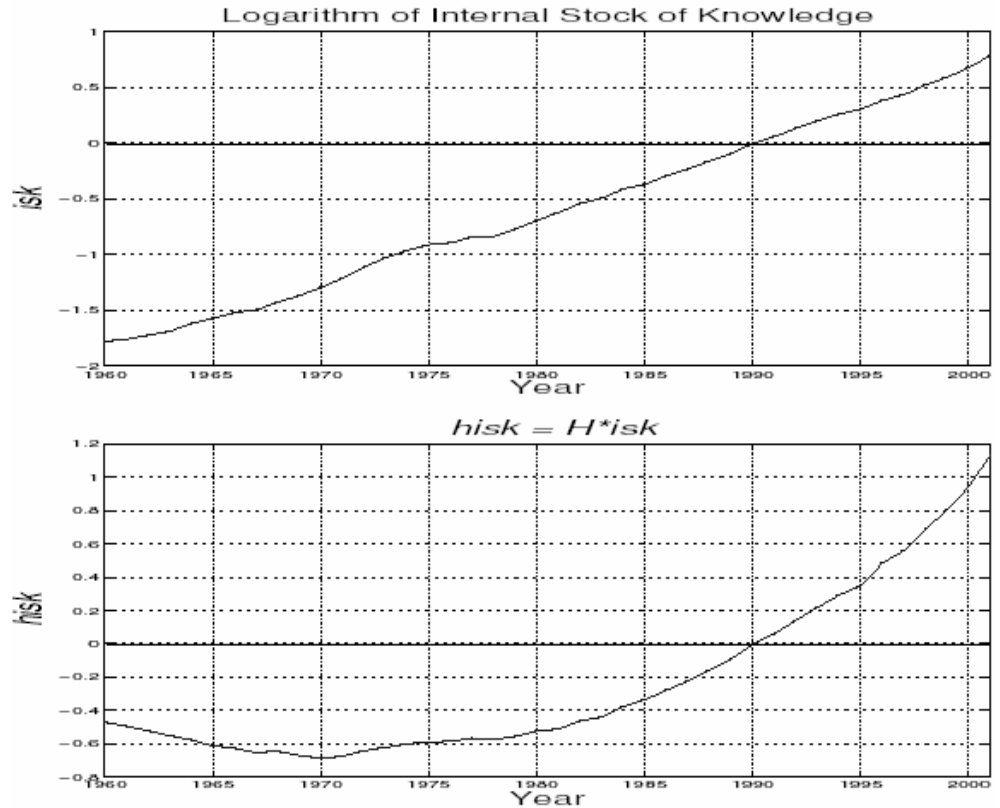

Fig. 1. Plots of the variables in levels 


\section{Tests for non-stationarity or unit roots}

Tests for non-stationarity or unit roots are presented in Tables 4-6. For the ADF test, we used the AIC with an upper bound for the lag length as the integer part of $12(T / 100)^{1 / 4}$ defined in Hayashi (2000), p. 594, where $T$ is the sample size. The upper bound for the data set considered in the paper is 9. For the PP test, the bandwidth parameter for the kernel-based estimator of the residual spectrum at frequency zero was obtained by the Newey-West (1994) method using Bartlett kernel.

Table 4. Unit root tests - variables in second differences

\begin{tabular}{crcrr}
\hline Series & Mean & ADF test & (lags) & PP test \\
\hline$f$ & -0.000950 & $-4.805^{*}$ & $(7)$ & $-27.009^{*}$ \\
$h$ & -0.000821 & $-6.902^{*}$ & $(1)$ & $-22.062^{*}$ \\
$i s k$ & 0.002277 & $-3.490^{*}$ & $(6)$ & $-12.501^{*}$ \\
hisk & 0.005346 & $-12.358^{*}$ & $(0)$ & $-11.934^{*}$ \\
\hline
\end{tabular}

Notes: For these series we specify a random walk (i.e., the AR model); MacKinnon (1991, 1996) critical values for rejection of hypothesis of a unit root, that is non-stationarity at $* 1 \%,{ }^{* *} 5 \%$ and $* * * 10 \%$.

Table 5. Unit root tests - variables in first differences

\begin{tabular}{cclcr}
\hline Series & Mean & ADF test & (lags) & PP test \\
\hline$f$ & 0.020143 & $-6.410^{*}$ & $(0)$ & $-6.521^{*}$ \\
$h$ & 0.041294 & $-4.505^{*}$ & $(0)$ & $-4.557^{*}$ \\
$i s k$ & 0.062714 & $-2.784^{* * *}$ & $(3)$ & $-4.567^{*}$ \\
hisk & 0.039209 & -1.576 & $(1)$ & $-5.500^{*}$ \\
\hline
\end{tabular}

Notes: For these series, excluding hisk, we specify a random walk with drift (i.e., the AR model with constant). In the case of hisk the AR model with constant and time trend was used instead; MacKinnon critical values for rejection of hypothesis of a unit root, that is non-stationarity at * $1 \%,{ }^{* *} 5 \%$ and ${ }^{* * *} 10 \%$. 
Table 6. Unit root tests - variables in levels

\begin{tabular}{ccccr}
\hline Series & Mean & ADF test & (lags) & PP test \\
\hline$f$ & -0.235272 & -2.774 & $(2)$ & -2.560 \\
$h$ & -0.324377 & -2.747 & $(0)$ & -2.747 \\
isk & -0.603531 & -1.196 & $(5)$ & -2.088 \\
hisk & -0.229400 & 2.907 & $(0)$ & 3.210 \\
\hline
\end{tabular}

Notes: For these series we specify a trend stationary form (i.e., the AR model with constant and time trend); MacKinnon critical values for rejection of hypothesis of a unit root, that is non-stationarity at * $1 \%,{ }^{* *} 5 \%$ and *** $10 \%$.

Legend for Tables 4-6: $f$ - natural logarithm of Portuguese TFP index 1960-2001; $h$ - natural logarithm of the index of average years of schooling of Portuguese adult population, 1960-2001; isk - natural logarithm of the index of Portuguese internal stock of knowledge, 1960-2001; hisk $=$ Hisk - where $H$ is the index of the average years of schooling of Portuguese adult population.

\section{References}

Abramovitz M (1986) Catching up, forging ahead, and falling behind. Journal of Economic History 46: 385-406

Abramovitz M (1993) The search for sources of growth: areas of ignorance, old and new. The Journal of Economic History 53(2): 217-243

Aghion P, Howitt P (1992) A model of growth through creative destruction. Econometrica 60(2): $323-$ 351

Aghion P, Howitt P (1998) Endogenous growth theory. MIT Press, Cambridge, MA

Arrow K (1962) The economic implications of learning by doing. Review of Economic Studies 29: 155-173. In: Stiglitz J, Uzawa H (eds) (1979) Readings in the modern theory of economic growth, 5th ed. MIT Press, Cambridge, MA

Autor D, Katz L, Krueger, A (1998) Computing inequality: have computers changed the labour market? Quarterly Journal of Economics 113(4): 1169-213

Azariadis C, Drazen A (1990) Threshold externalities in economic development. Quarterly Journal of Economics 105: 501-526.

Barreto A (1999) A situação social em Portugal, 1960-1996. Instituto de Ciências Sociais da Universidade de Lisboa, Lisboa

Barro R (1991) Economic growth in a cross-section of countries. The Quarterly Journal of Economics 106: $407-443$

Barro R, Lee J-W (1993) International comparisons of educational attainment. Journal of Monetary Economics 32: 363-394

Barro R, Lee J-W (1994) Sources of economic growth. Carnegie-Rochester Conference Series on Public Policy 40: 1-46

Barro R, Lee J-W (1996) International measures of schooling years and schooling quality. The American Economic Review 86(2): 218-223

Barro R, Lee J-W (2000) International data on educational attainment updates and implications. NBER Working Paper 7911

Becker G (1962) Investment in human capital: a theoretical analysis. Journal of Political Economy 70 : $9-44$

Benhabib J, Spiegel M (1994) The role of human capital in economic development: evidence from aggregate cross-country data. Journal of Monetary Economics 34: 143-173 
Berman E, Bound J, Machin S (1998) Implications of skill-biased technological change: international evidence. The Quarterly Journal of Economics 113(4): 1245-1279

Caballero R, Jaffe A (1993) How high are the giants' shoulders: an empirical assessment of knowledge spillovers and creative destruction in a model of economic growth. NBER Working Paper 4370

Caselli F, Esquivel G, Lefort F (1996) Reopening the convergence debate: a new look at cross-country growth empirics. Journal of Economic Growth 1: 363-389

Chuang Y-C (2000) Human capital, exports, and economic growth: a causality analysis for Taiwan, 1952-1995. Review of International Economics 8(4): 712-720

Cipolla C (1965) Guns, sails, \& empires. Pantheon Books, New York

Coe D, Helpman E (1995) International R\&D spillovers. European Economic Review 39(5): 859-87

Coe D, Helpman E, Hoffmaister A (1995) North-South R\&D spillovers. Economic Journal 107: 134-149

Cohen D, Soto M (2001) Growth and human capital: good data, good results. CEPR Discussion Paper Series 3025

Cohen W, Levinthal D (1990) Absorptive capacity: A new perspective on learning and innovation. Administrative Science Quarterly 35: 128-152

de la Fuente A (2003a) Human capital and national competitiveness. The state of the evidence. Instituto de Análisis Económico, CSIC

de la Fuente A (2003b) Human capital in a global and knowledge-based economy, Part II: assessment at the EU country level. Final report, European Commission: Employment and Social Affairs

de la Fuente A (2004) The macroeconomics of human capital. Instituto de Análisis Económico, CSIC

de la Fuente A, Ciccone A (2002) Human capital in a global and knowledge - based economy. Final report, European Commission

de la Fuente A, Doménech R (2002) Human capital in growth regressions: how much difference does data quality make? An update and further results. CEPR Discussion Paper 3587

Dickey D, Fuller W (1979) Distribution of the estimates for autoregressive time series with a unit root. Journal of the American Statistical Association 74: 427-431

Dickey D, Fuller W (1981) Likelihood ratio statistics for autoregressive time series with a unit root. Econometrica 49: 1057-1072

Dickey D, Jansen D, Thornton D (1991) A primer on cointegration with an application to money and income. In: Rao B (ed.) Cointegration for the applied economist, pp. 58-78. Macmillan, Basingstoke

Doms M, Dunne T, Troske K (1997) Workers, wages and technology. Quarterly Journal of Economics 112(1): 253-290

Engle R, Granger C (1987) Co-integration and error correction: representation, estimation and testing. Econometrica 55: 251-276

Fagerberg J. (1987) A technology gap approach to why growth rates differ. Research Policy 16: 87-99

Granger C (1969) Investigating causal relations by econometric models and cross spectral methods. Econometrica 37: 424-438

Granger C, Newbold P (1974) Spurious regressions in econometrics. Journal of Econometrics 2: 111120

Griliches Z (1988) Productivity puzzles and R\&D: another nonexplanation. Journal of Economic Perspectives 2(4): 9-21

Griliches Z (1995) R\&D and productivity: econometric results and measurements issues. In Stonemen P (ed) Handbook of the economics of innovation and technological change. Blackwell Publishing, London

Grossman G, Helpman E (1991/1992) Innovation and growth in the global economy, 2nd edn. MIT Press, Cambridge, MA London, England

Hanushek E (1996) Measuring investment in education. Journal of Economic Perspectives 10(4): 9-30

Harris R (1995) Using cointegration analysis in econometric modelling. Prentice Hall/Harvester, Wheatsheaf London

Hartog J, Pereira P, Vieira J (2001) Changing returns to education in Portugal during the 1980s and early 1990s: OLS and quantile regression estimators. Applied Economics 33: 1021-1037

Hayashi F (2000) Econometrics. Princeton University Press, Princeton NJ

Johansen S (1988) Statistical analysis of cointegration vector. Journal of Economic Dynamics and Control 12: 231-254

Johansen S, Juselius K (1990) Maximum likelihood estimation and inference on cointegration with application to the demand for money. Oxford Bulletin of Economics and Statistics 52: 169-209 
Jones C (1995) Time series tests of endogenous growth models. Quarterly Journal of Economics 110(2): $495-525$

Kortum S (1994) A model of research, patenting, and productivity growth. NBER Working Paper 4646 Kyriacou G (1991) Level and growth effects of human capital: a cross-country study of the convergence hypothesis. C.V. Starr Center for Applied Economics, New York University

Laroche M, Mérette M (2000) Measuring human capital in Canada. Department of Finance 2000-05

Levine R, Renelt D (1992) A sensitivity analysis of cross-country growth regressions. The American Economic Review 82(4): 942-963

Lucas R (1988) On the mechanics of economic development. Journal of Monetary Economics 22: 3-42

Lucas R (1990) Why doesn't capital flow from rich to poor countries? The American Economic Review 80(2): 92-96

MacKinnon J (1991) Critical values for cointegration tests. In: Engle R, Granger C (eds) Long-run economic relationships: readings in cointegration. Oxford University Press, Oxford

MacKinnon J (1996) Numerical distribution functions for unit root and cointegration tests. Journal of Applied Econometrics 11: 601-618

MacKinnon J, Haug A, Michelis L (1999) Numerical distribution functions of likelihood ratio tests for cointegration. Journal of Applied Econometrics 14: 563-577

Mankiw N, Romer D, Weil D (1992) A contribution to the empirics of economic growth. The Quarterly Journal of Economics 106(2): 407-437

Mansfield E (1975) International technology transfer: forms, resource requirement, and policies. American Economic Review 65: 372-376

Mulligan C, Sala-i-Martin X (1995) Measuring aggregate human capital. NBER Working Paper 5016

Nelson R, Phelps E (1966) Investment in humans, technological diffusion and economic growth. The American Economic Review 56(2): 69-75

Neves J (1994) The Portuguese economy: a picture in figures. Universidade Católica Editora, Lisboa

Newey W, West K (1994) Automatic lag selection in covariance matrix estimation. Review of Economic Studies 64(4): 631-653

OECD and Human Resources Development Canada (1988) Literacy skills for the knowledge society: further results from the international adult literacy survey, Paris and Ottawa

Pack H (1994) Endogenous growth theory: intellectual appeal and empirical shortcomings. Journal of Economic Perspectives 8(1): 55-72

Pereira J (2004) A medição do capital humano em Portugal. Master Dissertation, ISEG, Universidade Técnica de Lisboa

Phillips P, Perron P (1988) Testing for a unit root in time series regression. Biometrica 75: 335-346

Pina A, St. Aubyn M (2002) Public capital, human capital and economic growth: Portugal 1977-2001. Departamento de Prospectiva e Planeamento Ministério das Finanças, Portugal

Pritchett L (1995) Divergence, big time. World Bank - Country Economics Department, Paper 1522

Psacharopoulos G, Arriagada A (1986) La composition de la population active par niveau d'instruction: une comparaison internationale. Revue Internationale du Travail 125: 617-631

Rao B (1994) Cointegration: for the applied economist. Macmillan, Basingstoke

Romer P (1986) Increasing returns and long-run growth. Journal of Political Economy 94(5): 1002-1037

Romer P (1989) Capital accumulation in the theory of long-run growth. In: Barro R (ed) Modern business cycle theory. Harvard University Press, Cambridge, MA

Romer P (1990a) Endogenous technological change. Journal of Political Economy 98(5): S71-S101

Romer P (1990b) Human capital and growth: theory and evidence. Carnegie-Rochester Conference Series on Public Policy 32: 251-286

Rosenberg N (1976) Perspectives on technology. Cambridge University Press, Cambridge

Schultz T (1961) Investment in human capital. The American Economic Review 51(1): 1-17

Segerstrom P (1991) Innovation, imitation, and economic growth. Journal of Political Economy 99(4): $807-827$

Sianesi B, van Reenen J (2003) The returns to education: macroeconomics. Journal of Economic Surveys 17: $157-200$

Solow R (1956) A contribution to the theory of economic growth. The Quarterly Journal of Economics 70: 65-94 
Teixeira A. C (1996) Capacidade de inovação e capital humano. Contributos para o estudo do crescimento económico português, 1960-1991. Master Dissertation, Faculdade de Economia da Universidade do Porto

Teixeira A. C (1998) Human capital stock: an estimation of a time series for Portugal. Estudos de Economia 18(4): 423-441

Teixeira A. C (2004a) Measuring aggregate human capital in Portugal. An update up to 2001. FEP Working Paper 152, Faculdade de Economia da Universidade do Porto

Teixeira A. C (2004b) How has the Portuguese innovation capability evolved? Estimating a time series of the stock of technological knowledge, 1960-2001. FEP Working Paper 153, Faculdade de Economia da Universidade do Porto

Verspagen B (1993) Uneven growth between interdependent economies: An evolutionary view on technology gaps, trade and growth. Avebury, Aldershot

Wossmann L (2003) Specifying human capital. Journal of Economic Surveys 17(3): 239-270 